INOBIS: Jurnal Inovasi Bisnis dan Manajemen Indonesia

Volume 1, Nomor 1, Desember 2017

Tuwanku Aria Auliandri

\title{
Analisa Aktivitas Manajemen Strategi pada Industri Pariwisata Berbasis Digital
}

\author{
Tuwanku Aria Auliandri \\ Program Doktor Ilmu Manajemen - Universitas Brawijaya \\ tuwanku@gmail.com
}

\begin{abstract}
Abstrak
Aktivitas pariwisata terdiri dari beragam proses mulai dari regulasi pemerintah yang mendukung, pemilihan lokasi wisata yang baik, promosi lokasi wisata, hingga pada pelayanan kepada wisatawan. Konsep Manajemen Strategis mengakomodir hal tersebut dan Teknologi berperan membantu Industri Pariwisata untuk masuk ke era digital dimana segala proses bisa diintegrasikan dengan Internet. Pemilihan strategi yang tepat dapat mengembangkan Industri pariwisata di suatu wilayah dan memberi nilai tambah kepada stakeholder di wilayah tersebut. Seluruh unsur yang terkait dengan aktivitas manajemen strategi pada industri pariwisata berbasis digital akan diulas dengan mengacu pada referensi jurnal terbaru yang bersesuaian di tiap bahasan.
\end{abstract}

Keywords: Manajemen strategi ; Regulasi Pemerintah ; Lokasi wisata; Wisata daerah kepulauan; Inovasi produk dan jasa; Teknologi pendukung pariwisata; Promosi wisata;

\section{Latar Belakang}

Keindahan alam di suatu negara merupakan sebuah anugerah yang bisa dioptimalkan potensinya sehingga menghasilkan kontribusi positif bagi negara. Panorama alam yang indah bukanlah sebuah hasil produksi atau rancangan perusahaan, namun telah seketika hadir dan siap untuk dirawat dan di komersialkan untuk tujuan yang positif. Industri Pariwisata di sebuah negara hadir untuk mengakomodir keinginan wisatawan untuk melihat dan menikmati beragam panorama alam yang dibalut dengan bentukan paket kunjungan wisata.

Aktivitas pariwisata terdiri dari beragam proses mulai dari regulasi pemerintah yang mendukung, pemilihan lokasi wisata yang baik, promosi lokasi wisata, hingga pada pelayanan kepada wisatawan. Teori Manajemen Strategis mengakomodir hal tersebut dan Teknologi berperan membantu Industri Pariwisata untuk masuk ke era digital dimana segala proses bisa diintegrasikan dengan Internet.

Manajemen strategi adalah seni dan pengetahuan dalam merumuskan, mengimplementasikan, serta mengevaluasi keputusan-keputusan lintas fungsional yang memungkinkan sebuah organisasi untuk mencapai tujuan (Davis, 2011). Manajemen strategis berfokus pada proses penetapan tujuan organisasi, pengembangan kebijakan dan perencanaan untuk mencapai sasaran, serta mengalokasikan sumber daya untuk menerapkan kebijakan dan merencanakan pencapaian tujuan organisasi.

Menurut Davis (2011), proses manajemen strategis terdiri dari tiga tahapan, yaitu :

- Perumusan Strategi (Strategy Formulation) 
INOBIS: Jurnal Inovasi Bisnis dan Manajemen Indonesia

Volume 1, Nomor 1, Maret 2018

\section{Tuwanku Aria Auliandri}

- Perumusan strategi adalah tahap awal pada manajemen strategi, yang mencakup mengembangkan visi dan misi, mengidentifikasi peluang eksternal organisasi dan ancaman, menentukan kekuatan dan kelemahan internal, menetapkan tujuan jangka panjang, menghasilkan strategi alternatif, dan memilih strategi tertentu untuk mencapai tujuan.

- Implementasi Strategi (Strategy Implemented)

- Implementasi strategi ini memerlukan suatu keputusan dari pihak yang berwenang dalam mengambil keputusan untuk menetapkan tujuan tahunan, menyusun kebijakan, memotivasi karyawan, dan mengalokasikan sumber daya sehingga strategi yang dirumuskan dapat dilaksanakan. Pada tahap ini dilakukan pengembangan strategi pendukung budaya, merencanakan struktur organisasi yang efektif, mengatur ulang usaha pemasaran yang dilakukan, mempersiapkan budget, mengembangkan dan utilisasi sistem informasi serta menghubungkan kompensasi karyawan terhadap kinerja organisasi.

- Evaluasi Strategi (Strategy Evaluation)

- Evaluasi strategi diperlukan oleh perusahaan karena strategi yang berhasil untuk saat ini tidak selalu berhasil untuk di masa yang akan datang. Dalam penilaian strategi terdapat tiga aktivitas penilaian yang mendasar, yaitu:

- Peninjauan ulang faktor-faktor eksternal dan internal yang menjadi landasan bagi strategi saat ini,

- Pengukuran kinerja, dan

- Pengambilan langkah korektif.

Pemilihan strategi yang tepat dapat mengembangkan Industri pariwisata di suatu wilayah dan memberi nilai tambah kepada stakeholder di wilayah tersebut. Seluruh unsur yang terkait dengan aktivitas manajemen strategi pada industri pariwisata berbasis digital akan diulas dengan mengacu pada referensi jurnal terbaru yang bersesuaian di tiap bahasan.

\section{Tujuan}

Tujuan dari tulisan ini adalah untuk menganalisa aktivitas manajemen strategi pada industri pariwisata berbasis digital, berdasarkan referensi pada penelitian sebelumnya, yang berfokus pada unsur pengembangan pariwisata berikut:
a. Unsur regulasi pemerintah
b. Unsur lokasi wisata di daerah kepulauan
c. Unsur inovasi produk dan jasa
d. Unsur teknologi untuk mendukung industry pariwisata
e. Unsur promosi untuk menjual lokasi wisata

\section{Regulasi pemerintah untuk mendorong pariwisata}

Transportasi udara menggunakan pesawat komersial berjadwal merupakan simpul penting yang perlu diurai untuk bisa melancarkan kedatangan wisatawan berkunjung ke suatu wilayah. Wilayah Indonesia yang berbasis kepulauan merupakan peluang bagi industry penerbangan untuk bisa membuka rute baru ke wilayah wisata di beragam daerah di Indonesia. Namun disisi lain juga terdapat hambatan dimana pemerintah memiliki aturan ketat perihal pembukaan rute baru untuk perusahaan penerbangan, yang mempertimbangkan standard keamanan utamanya di Bandar udara. Hal lain yang juga menjadi hambatan adalah 
INOBIS: Jurnal Inovasi Bisnis dan Manajemen Indonesia

Volume 1, Nomor 1, Maret 2018

\section{Tuwanku Aria Auliandri}

berkait dengan otoritas Imigrasi yang memiliki jumlah personel terbatas sehingga berakibat pada lambannya pihak imigrasi untuk bisa hadir di banyak Bandar udara di seluruh wilayah Indonesia.

Beragam hal tersebut yang melatarbelakangi pemerintah untuk merevisi beragam aturan yang menghambat perkembangan indutsri pariwisata di daerah. Website detik.com pada artikelnya di tanggal 29 November 2016, menyajikan liputan tentang keberhasilan Presiden Joko Widodo meningkatkan kunjungan wisatawan asing, utamanya dari China, ke wilayah Manado yang sebelumnya hanya 12.000 orang per tahun, dan saat ini menjadi 12.000 orang per bulan.

Ungkapan sukses ini disampaikan Presiden di depan peserta acara Seminar Forbes Global CEO Performance di Jakarta. Presiden mengungkapkan bahwa upaya pengembangan pariwisata di Manado ini merupakan bukti bahwa regvisi regulasi penerbangan yang mendukung perusahaan penerbangan untuk mempercepat persetujuan pengajuan rute International baru, terbukti telah membuahkan hasil. Pihak Imigrasi telah hadir di Airport Manado, dan secara otomatis akan memudahkan wisatawan dari mancanegara untuk langsung masuk ke Manado tanpa harus transit terlebih dahulu di Bandar udara Jakarta atau Surabaya atau bali. Hal ini menunjukkan bahwa pemerintah yang proaktif untuk merubah regulasi di industry penerbangan dan menyesuaikan dengan kebutuhan pasar, berimplikasi positif pada pertumbuhan sektir industry pariwisata di daerah.

\section{Pengembangan potensi pariwisata di daerah kepulauan}

Industri pariwisata mayoritas berfokus pada eksploitasi keindahan alam. Lokasi wisata berbasis kepulauan memiliki kelebihan karena menawarkan hal baru bagi wisatawan yang berasal dari daerah perkotaan. Matahari terbit dan Matahari tenggelam serta pasir pantai dan debur ombak merupakan sajian utama dari lokasi wisata kepulauan. Karena lokasi nya yang berada di sebuah pulau maka secara geografis lokasi ini cenderung terisolir, sehingga stakeholder industry wisata di pulau tersebut perlu untuk berkolaborasi aktif dengan sesamanya sehingga bisa menghidupkan wisata di pulau tersebut.

Artikel dengan judul "Sustainable Tourism Development in Island: A Case Study of Gran Canaria", yang diterbitkan oleh Jurnal "Business Strategy and Environment, 1999" berupaya untuk menjelaskan tentang upaya Stakeholder di Pulau Gran Canaria untuk menghidupkan industry pariwisatanya.

Secara umum industry pariwisata dapat meningkatkan jumlah pekerja, meningkatkan pendapatan masyarakat, memunculkan infrastruktur pembangunan di wilayah, sehingga bisa menggerakan perekonomian di suatu wilayah (Liu et al, 1987). Pemerintah di Pulau Gran Canaria mengupayakan Strategic Planning untuk bisa menggerakan perekonomian berbasis wisata di daerahnya, dengan konsep: (1) Mengidentifkasi rantai pasok pada industry pariwisata, (2) Mengidentifikasi rencana jangka panjang yang bersesuaian dengan lingkungan wilayah, (3) Memberdayakan masyarakat sebagai agen perubahan yang bisa mengupayakan industry pariwisata, dan (4) Memunculan "Sustainable Development" terhadap semua factor pariwisata tersebut.

Kepulauan Gran Canaria adalah salah satu dari 7 pulau yang menjadi bagian dari Negara Spanyol. Total luas pulau ini adalah $1560 \mathrm{~km} 2$, dengan jumlah penduduk 714.000 orang. Iklim di pulau ini adalah semi tropis dengan suhu berkisar diantara 18 derajat celcius di bulan maret, dan 25 derajat celcius di bulan oktober. Kemiskinan juga menjadi issue di pulau ini, dengan jumlah pengangguran sejumlah $19 \%$. Hal ini terjadi sebagai akumulasi akibat dari adanya 25\% masyarakat yang buta huruf yang terjadi di tahun 1991, dan hanya $6 \%$ yang 
INOBIS: Jurnal Inovasi Bisnis dan Manajemen Indonesia

Volume 1, Nomor 1, Maret 2018

\section{Tuwanku Aria Auliandri}

meneruskan pendidikannya hingga ke level Universitas. Penduduk di Pulau Gran Canaria, sejumlah $70 \%$ diantaranya bekerja di sector jasa pariwisata

Wisata berbasis lingkungan banyak digalakan oleh pemerintah local dengan berfokus pada: (1) Wisata Bio Diversity, (2) Wisata Wilayah pesisir pantai, dan (3) Wisata Hutan. Semua aktivitas wisata tersebut membuat pemerintah local untuk memperhatikan beragam dampak lingkungan dan dampak ekonominya. Salah satu dampak lingkungan yang muncul adalah perlunya pemenuhan kebutuhan air untuk warganya, dengan mengupayakan $16 \%$ air dari proses destilasi air laut, dan $84 \%$ adalah penampungan air hujan.

Pengembangan pariwisata tentunya memperhatikan jumlah penginapan untuk wisatawannya. Data menunjukan di tahun 1996 terdapat 126.179 tempat tidur yang tersebar di 168 hotel dan 716 apartemen / bungalow, dengan hotel standard bintang 3 dan 4 sejumlah $73 \%$, dan hotel standard bintang 5 sejumlah 7\%. Semua infratruktur tersebut bermanfaat untuk menampung jumlah turis sebanyak 2,6 juta di tahun 1996. Tourist berdatangan dari beragam wilayah di sekitar eropa, yang mayoritas dari Negara Jerman 36\%, dan Inggris $21 \%$. Para wisatawan dari hasil penelitian ini menyebutkan bahwa pantai merupakan tujuan utama mereka datang di pulau ini (39\%), akomodasi dengan biaya terjangkau (28\%), entertainment dan restaurant (14\%), dan menikmati pemandangan yang indah (17\%).

Penelitian ini menghasilkan rekomendasi untuk menghadirkan sustainable development di pulai Grand Canaria, yaitu :

a. Konsolidasi wisata pantai dan wisata matahari terbit

b. Diversifikasi wisata pantai dan wisata matahari terbit

c. Diversifikasi bentukan wisata baru

d. Mengidentifikasi Issue Sosial

e. Mengidentifikasi Issue Lingkungan

f. Manajemen Sumber daya alam dengan baik

g. Mengikutsertakan politik dalam mengembangkan unsur wisata.

Peneliti melihat bahwa pemerintah local di Pulau Gran Canari berfokus untuk mengoptimalkan pendapatan daerahnya dari sumber pariwisata karena memang asset wisata telah hadir di wilayah tersebut. Online platform juga telah dikembangkan oleh pemerintah setempat untuk mendukung konsep ini. Pengelolaan asset wisata di kepulauan perlu diupayakan diversifikasinya sehingga bisa dioptimalkan untuk bisa mendatangkan wisatawan yang beih banyak di masa mendatang. Konsep "Sustainable Tourism" relevan untuk diangkat menjadi topic konservasi pariwisata di pulan Gran Canari.

\section{Mengubah suatu masalah menjadi peluang yang berkontribusi nilai tambah}

Aktivitas operasional perusahaan yang rutin terkadang memunculkan permasalahan yang perlu untuk diantisipasi solusinya. Penanganan solusi yang tepat dapat menyelesaikan permasalahan tersebut bahkan memunculkan adanya peluang baru bagi perusahaan sehingga bisa menghasilkan inovasi produk baru yang merupakan pengembangan dari eksisting produk. Infrastruktur Online perusahaan juga mempercepat proses komunikasi Internal dan berujung pada beragam Innovasi hadir dengan cepat di perusahaan.

Artikel dengan judul "Strategy, Problems, and a Theory for the Firm" yang diterbitkan oleh "Organization Science, Articles in Advance (2015)" menjelaskan tentang adanya sebuah model bagi perusahaan untuk merubah sebuah problem di perusahaan yang kemudian dikonversi menjadi peluang yang kemudian memberikan nilai tambah bagi perusahaan. Model ini telah diterapkan pada perusahaan Starbucks dan Apple yang diterima dengan baik oleh 
INOBIS: Jurnal Inovasi Bisnis dan Manajemen Indonesia

Volume 1, Nomor 1, Maret 2018

Tuwanku Aria Auliandri

konsumennya. Perusahaan tersebut telah mengidentifikasi dengan jelas kekuatan internal perusahaannya, dan dengan sadar menunggu feedback dari konsumennya. Saat feedback tersebut muncul, maka tim internal dari perusahaan telah memiliki system yang tepat untuk mengelola problem dan memperbaikinya serta membuat produk / jasa baru yang kemudian berujung pada nilai tambah pada konsumennya.

\section{Pemanfaatan teknologi untuk menunjang industry pariwisata}

Era digital saat ini memberi kemudahan calon wisatawan untuk dapat melakukan pencarian informasi di internet berkaitan dengan tujuan wisata yang akan dikunjungi. Informasi yang didapat dari Internet akan memudahkan wisatawan untuk memilih tujuan wisata yang sesuai dengan preferensi mereka. Penggunaan teknologi ini tidak lepas dari semakin mudahnya user untuk memiliki gadget atau computer yang terhubuung dengan akses internet. Stakeholder di industry pariwisata juga telah memahami hal ini dan pun juga telah membuat website sehingga memudahkan calon wisatawannya untuk mencari informasi yang berkaitan dengan lokasi wisatanya.

Artikel dengan judul "Re-Exemining Perceived usefulness and ease of use in online booking - The case of hongkong online user", yang diterbitkan oleh "International Journal of Contemporary Hospitality Management - Vol 27, No 2, 2015" berupaya untuk menjelaskan tentang wisatawan di Hongkong yang menggunakan Internet sebagai upaya untuk mencari tujuan wisata yang akan dikunjungi.

Penelitian ini dilakukan di Hongkong pada periode maret - april 2013, dengan jumlah total responden sebanyak 213 orang yang telah mengisi data dengan valid. Responden laki laki sejumlah $42 \%$ dan responden wanita sebanyak 58 persen. Usia responden paling banyak $59 \%$ adalah di range usia 18-25 tahun, dan 68\% diantaranya telah melakukan aktivitas pembelian produk wisata secara online dalam masa 5 tahun terakhir. Mayoritas responden sebanyak 32\% adalah pelajar, dan 85\% dari seluruh responden mengakses internet setiap hari.

Technology Acceptance Model (TAM) dari Davis (1989) menjadi acuan yang dipakai oleh peneliti untuk merancang kuisionernya. Isian kuisioner terbagi menjadi 3 bagian yaitu:

1. Perceived Usefulness

a. Easy Booking

b. Usefulness in Booking

c. Fast Booking

d. Efficient Booking

2. Ease of Use

a. Easy to Learn

b. Less requierement of mental effort

c. Being Simple

d. Easy to follow instruction

3. Behavior Intention

a. Willingness to use internet in the future to book online

b. Willingness to frequently use internet in the future to book online

c. Recommend other to book online

Penghitungan kuisioner penelitian menggunakan software Statistical Package for Social Science (SPSS). Analisa Deskriptive dan Statistik Inferensial dari sample data 
INOBIS: Jurnal Inovasi Bisnis dan Manajemen Indonesia

Volume 1, Nomor 1, Maret 2018

\section{Tuwanku Aria Auliandri}

dilakukan dengan menggunakan teknik Exploratory Factor Analysis (EFA), Rata rata dan Standard Deviasi, Independent T-Test, One Way Anova, dan Analisa Regresi.

Hasil dari penelitian menunjukkan bahwa user dengan usia muda mendominasi pengguna Online Booking, sedangkan user yang lebih senior lebih memilih pada bentuk Tradisional yang mendatangi Travel Agent secara langsung (Face to Face Intention). Hal lain yang dimunculkan adalah bahwa user senior tidak memahami keuntungan menggunakan internet sebagai aktivitas pemesanan wisatanya, walaupun pihak Travel Agent telah mengarahkan user senior tersebut untuk bertransaksi Online Booking untuk mendapatkan beragam manfaat lebih.

Pada pengguna interenat secara harian, dan untuk responden di usia muda, terdapat hasil penelitian yang menyebutkan bahwa responden pada type ini lebih mengiginkan "Perceived of Usefulness" dibanding "Ease to use". Konsep "Usefulness" pada penelitian ini mengacu pada adalah Informasi yang baik, Akses yang cepat, Efisien dan mudah dalam pencarian. Menyikapi hal tersebut, seluruh responden sepakat bahwa website dari tujuan wisata sangat penting sebagai upaya untuk menghadirkan "Usefulness" dalam proses Online Booking. Website yang baik menjadi penggerak utama bagi user di Internet untuk memutuskan lokasi kunjungan wisata berikutnya, sehingga ini dapat menggerakan tim marketing untuk bisa mendesain promosi yang menarik untuk calon pelanggan di Online Booking.

\section{Promosi destinasi wisata berbasis Electronic Word of Mouth (eWOM)}

Konsumen yang datang ke sebuah destinasi wisata akan memiliki ekspektasi terhadap lokasi kunjungannya tersebut. Setelah wisatawan berkunjung maka akan muncul tanggapan dari lokasi wisata tersebut. Kepuasan yang didapat oleh wisatawan tersebut akan memunculkan efek berbagi pengalaman dengan calon wisatawan lainnya. Secara lisan ataupun tulisan, baik online maupun offline, wisatawan tersebut akan mengkomunikasikan pengalaman berwisatanya kepada rekannya. Tidak hanya kepuasan yang akan disampaikan, namun juga ketidakpuasan juga akan dimunculkan. Hal tersebut diduga akan mempengaruhi proses pengambilan keputusan oleh calon wisawatan yang lain.

Artikel dengan judul "What drives café customers to spread eWOM ? Examining self relevant value, quality value, and opinion leadership", yang diterbitkan oleh "International Journal of Contemporary Hospitality Management, April 2014" berupaya untuk menjelaskan tentang adanya upaya oleh konsumen untuk sharing pengalamannya kepada rekannya yang lain, dengan menggunakan konsep Word of Mouth (WOM).

Pada penelitian ini peneliti berfous pada motivasi responden terhadap upayanya untuk melakukan eWOM. Apabila pada penelitian sejenis hanya dilakukan untuk meneliti tentang kualitas yang diterima oleh responden, maka khusus untuk penelitian eWOM ini maka responden tidak hanya telah menyelesaikan aktivitasnya pada kegiatan tersebut, namun juga termotivasi untuk menyebarkan pengalamannya kepada orang lain (Jeong and Jam, 2011). Hal lain yang juga muncul dari penelitian ini adalah adanya "Opinion Leadership" yang ternyata melakukan upaya untuk mendorong opini terhadap suatu pendapat dalam sebuah forum diskusi (Lyons and Henderson, 2005).

Responden penelitian ini didapat dari konsumen dari café "Coffee Smith" yang berlokasi di Gangnam Seoul, South Korea. Total 380 kuisioner dibagikan kepada pengunjung oleh karyawan café, dan terdapat 330 valid quisioner yang dapat diolah lebih lanjut untuk dilakukan analisa penelitian. Rata-rata usia responden adalah 26 tahun, dengan jumlah responden wanita adalah 58\%. Jumlah responden dengan gelar sarjana adalah 94\%, dan mayoritas responden belum menikah (96\%). 
INOBIS: Jurnal Inovasi Bisnis dan Manajemen Indonesia

Volume 1, Nomor 1, Maret 2018

Tuwanku Aria Auliandri

Quisioner penelitian mengacu pada penelitian terdahulu perihal "Perceived Café Quality" oleh Jang and Namkung (2009). Data analysis menggunanakan Confirmatory Factor Analysis (CFA) untuk memunculkan model penelitian, kemudian Structural Equation Modelling (SEM) digunakan untuk cek hipotesis-1 hingga hipotesis-5. Semua analysis tersebut menggunakan Analysis of Moment Structure (AMOS 19.0)

Hasil penelitian menunjukan bahwa konsumen muda termotivasi untuk melakukan eWOM. Pada kasus ini dimana seluruh responden adalah warga korea, hal ini sesuai dengan penelitian terdahulu bahwa konsumen muda ingin menunjukkan "Individual Identity" terhadap didalam sebuah komunitas. Harga produk dari sebuah aktivitas juga tidak menjadi faktor utama yang akan di sharing melalui eWOM, namun kepuasan saat mendapatkan fasilitas tersebut menjadi hal yang paling utama. Kepuasan konsumen setelah merasakan aktivitas tersebut merupakan refleksi dari "Individual Identity" dari setiap konsumen.

Analisa hasil penelitian lain juga menunjukkan bahwa "Opinion Leader" memberikan peran penting terhadap eWOM. Opinion Leader ini kerap dijadikan rujukan oleh rekan lainnya sehingga bisa mencoba layanan tersebut. Opinion Leader ini memiliki pengetahuan dan pengalaman sehingga mereka menonjol didalam komunitasnya (Bertrandias and Goldsmith, 2006)

Penelitian ini menyimpulkan bahwa eWOM memliki peran penting untuk dapat menghidupkan suatu lokasi kunjungan wisata. Opinion Leader perlu diidentifikasi sehingga bisa menciptakan pola kunjungan yang kemudian akan diikuti oleh calon pengunjung lainnya yang memiliki preferensi yang sama dengan opinion leader tersebut. Profil responden juga perlu diidentifikasi yang disesuaikan dengan target market konsumen di lokasi wisata tersebut.

\section{Kesimpulan}

Aktivitas pariwisata terdiri dari beragam proses mulai dari regulasi pemerintah yang mendukung, pemilihan lokasi wisata yang baik, promosi lokasi wisata, hingga pada pelayanan kepada wisatawan. Teori Manajemen Strategis mengakomodir hal tersebut dan Teknologi berperan membantu Industri Pariwisata untuk masuk ke era digital dimana segala proses bisa diintegrasikan dengan Internet.

Pemilihan strategi yang tepat dapat mengembangkan Industri pariwisata di suatu wilayah dan memberi nilai tambah kepada stakeholder di wilayah tersebut. Seluruh unsur yang terkait dengan aktivitas manajemen strategi pada industri pariwisata berbasis digital telah diulas dengan mengacu pada referensi jurnal terbaru yang bersesuaian di tiap bahasan.

Beragam hasil penelitian berkaitan aktivitas manajemen strategi pada industri pariwisata berbasis digital, dapat disimpulkan sebagai berikut:

a. Berhubungan dengan unsur regulasi pemerintah:

Isu terkini menunjukkan bahwa pemerintah yang proaktif untuk merubah regulasi di industry penerbangan dan menyesuaikan dengan kebutuhan pasar, berimplikasi positif pada pertumbuhan sektir industry pariwisata di daerah.

b. Berhubungan dengan unsur lokasi wisata di daerah kepulauan:

Hasil penelitian menunjukkan bahwa Konsep "Sustainable Tourism" dan "Diversifikasi Lokasi Wisata" relevan untuk diangkat menjadi topic pengembangan pariwisata di wilayah kepulauan.

c. Berhubungan dengan unsur inovasi produk dan jasa : 
INOBIS: Jurnal Inovasi Bisnis dan Manajemen Indonesia

Volume 1, Nomor 1, Maret 2018

Tuwanku Aria Auliandri

Hasil penelitian menunjukkan bahwa terdapat model bagi perusahaan untuk merubah sebuah problem di perusahaan yang kemudian dikonversi menjadi peluang yang kemudian memberikan nilai tambah bagi perusahaan.

d. Berhubungan dengan unsur teknologi untuk mendukung industry pariwisata:

Hasil penelitian menunjukkan bahwa responden pada usia muda lebih mengiginkan "Perceived of Usefulness" dibanding "Ease to use". Konsep "Usefulness" pada penelitian ini mengacu pada adalah Informasi web yang baik, Akses web yang cepat, Efisien dan mudah dalam pencarian.

e. Berhubungan dengan unsur promosi untuk menjual lokasi wisata:

Hasil penelitian menunjukkan bahwa Electronic Word of Mouth (eWOM) memliki peran penting untuk dapat menghidupkan suatu lokasi kunjungan wisata, dan Opinion Leader perlu diidentifikasi sehingga bisa menciptakan pola kunjungan yang kemudian akan diikuti oleh calon wisatawan lainnya.

\section{Daftar Pustaka}

Deniz Kucukusta, Rob Law, Alia Besbes \& Patrick Legohérel (2015), Re-examining perceived usefulness and ease of use in online booking - The case of Hong Kong online users, International Journal of Contemporary Hospitality Management, (Vol. 27 No. 2), 185-198

DongHee Kim, Soo Cheong Jang \& Howard Adler (2015), What drives café customers to spread eWOM ? Examining self relevant value, quality value, and opinion leadership, International Journal of Contemporary Hospitality Management, (27).

Fred David, Forest David (2011), Strategic Management - Concept and Cases, (Pearson: Fifteenth Edition)

Juan Manuel Garcia-Falcon, \& Diego Medina-Munoz (1999), Sustainable Tourism Development in Islands: A Case Study of Gran Canaria, Business Strategy and the Environment, (8), 336-357.

Muhammad Idris (2016), Jokowi: Turis China ke Manado Sekarang 12.000 orang / Bulan, dulu 12.000 orang / Tahun, < http://finance.detik.com/ekonomi-bisnis/3358136> [Diakses 29 Nov 2016]

Teppo Felin, Todd R. Zenger (2015); Strategy, Problems, and a Theory for the Firm; Organization Science, Articles in Advance, 1-10. 